\title{
DETECTION OF LUNG CANCER IN A MALE INDUSTRIAL POPULATION
}

\author{
BY \\ K. P. DUNCAN AND R. W. HOWELL \\ United Kingdom Atomic Energy Authority, Authority Health and Safety Branch, Radiological Protection Division, \\ Harwell, Berkshire
}

From time to time it has been suggested that changes should be made in the pattern of routine radiological supervision of employees in industry. Routine diagnostic $x$-ray practice in the United Kingdom Atomic Energy Authority has varied both over the years and between establishments, but about three-quarters of all male employees have been $x$-rayed at approximately yearly intervals, and almost all the rest have been $x$-rayed at intervals of 2 to 3 years. Almost all the films taken are full-size plates. The cases in the present series arose from approximately 230,000 man-years of exposure to the risk of lung cancer; about 120,000 man-years of exposure arose in those over 40 years of age.

While the incidence of cancer of the lung has increased, it has been reported by others (Bignall, 1959: Posner, McDowell, and Cross, 1963: Rosenblatt and Lisa, 1956: Shanks and Kerley, 1962) that cases found by routine $x$ ray had a disappointing prognosis. The majority of lung cancer cases detected by mass miniature radiography in recent years stems from general practitioner referrals and other selected groups.

This note is concerned with 141 cases of primary cancer of the lung, bronchus, and trachea (International Statistical Classification: $162 \cdot 1$ ) in males in whom the diagnosis was made before 1965 . The cases diagnosed in 1965 have been left in abeyance since their survival time must be limited. No cases have been lost to follow-up. The source of the information is an industrial medical record augmented by follow-up inquiry.

The population on which this study is based is fairly typical of the national industrial structure except that there is a slightly raised proportion of Social Classes I, II, and III, and less than the average proportion of heavy manual workers.
Number and Age Distribution of Cases In spite of the more favourable prognosis indicated in some of the highly selected published series, lung cancer is still a lethal disease, with something like 85 to 90 per cent. of registered cases dying within $1 \mathrm{~S}^{\mathrm{S}}$ months of registration (Ministry of Health, 1960 에 South Metropolitan Cancer Registry, 1960, 1961, 1963). This present series is also a selected one, sigce the peak incidence in the general population is aroư 70 years, with an average age for all cases of absitit 63 years; the Authority cases ranged from age $\$ \$$ years ( 2 cases) to age 69 years $(2$ cases), with ap average age of 56 years. Although peak numbers arose in the 55 to 64-year age group (Table Io because of the smaller number at risk in the olde? age groups, incidence rose with age as with the national figures.

52 per cent. of these cases were discovered b U.K.A.E.A. Medical Departments, though the proportion varied between establishments; most of these were diagnosed following routine $x$-ray exam $-\overline{-}$ ination. This is a distinct contrast to most othe? series; conditions obtaining in industry may mear. that the general conclusions reached by others mas not be entirely applicable here. It is of interest to note, however, that the sixteen survivors were spread over all age groups, with an average age of 55 yearsp against 56 years for the series as a whole.

\section{INCIDENCE}

Accurate staff numbers, by age, were availables for the years 1960-64 inclusive, and in conjunction with those cases first diagnosed in this period Authority age-specific rates are shown in Table $\Phi$ (opposite).

Since the 5-year survival rate for lung cancer in males is of the order of 4 per cent. (Ministry of 
Health, 1960), it is likely that incidence rates of lung cancer in England and Wales are not much higher than death rates. The 1960-64 Authority incidence is therefore compared with the 1964 death rates for England and Wales (Registrar General, 1966). Also shown in Table $I$ are the incidence rates experienced by the South Metropolitan Cancer Registry for 1960 (published 1963).

TABLE I

AUTHORITY CASES BY AGE AND AGE-SPECIFIC INCIDENCE OF LUNG CANCER IN MALES

\begin{tabular}{c|c|c|c|c}
\hline $\begin{array}{c}\text { Age } \\
\text { Group } \\
\text { (yrs) }\end{array}$ & $\begin{array}{c}\text { No. of } \\
\text { Author- } \\
\text { ity } \\
\text { Cases }\end{array}$ & $\begin{array}{c}\text { Incidence per } \\
1,000 \text { Staff per } \\
\text { annum } \\
\text { (UKAEA, } \\
\text { 1960-4) }\end{array}$ & $\begin{array}{c}\text { Incidence per } \\
1,000 \text { Males } \\
\text { (SMCR, 1960) }\end{array}$ & $\begin{array}{c}\text { Death Rate per } \\
\text { 1,000 Popu- } \\
\text { lation } \\
\text { (England and } \\
\text { Wales, 1964) }\end{array}$ \\
\hline $35-44$ & 8 & $0 \cdot 1$ & $0 \cdot 2$ & $0 \cdot 1$ \\
$45-54$ & 43 & $0 \cdot 7$ & $1 \cdot 0$ & 0.7 \\
$55-64$ & 77 & $2 \cdot 5$ & $3 \cdot 2$ & $2 \cdot 1$ \\
$65-69$ & 13 & $4 \cdot 1$ & $4 \cdot 1$ & 3.5 \\
\hline
\end{tabular}

\section{SURVIVORS}

Sixteen men are still alive, with survival times ranging from 14 months to 10 years, with histological confirmation of the diagnosis in all cases. Boucot, Cooper, and Weiss (1961) have stated that there are few truly asymptomatic cases not apparent on careful radiological examination, but if these symptoms are too insignificant to bring the patient to consultation, he may well be regarded as symptom-free in this context. Fifteen of the sixteen survivors were discovered in Authority medical departments. Fourteen of these fifteen Authority-discovered patients were found by routine $x$-ray examination. Eleven of the fifteen were symptom-free, for three details were not recorded, and for one only were there known symptoms.

\section{5-Year Survival Rates}

Not only are most currently published series highly biased in their selection of patients (particularly surgical series), but survival rates are not generally calculated by Life Table methods. It may therefore be reasonable to accept the Ministry of Health (1960) estimate of a 4 per cent. 5-year survival rate in males as typical of experience in this country. In other large series, Kutschera (1964) found a 4-year survival of about 2 per cent. (13,000 males and females combined), and the California Tumor Registry (1963) had a 5-year survival rate of about 4 per cent. in just over 5,000 male patients. Table II shows 5-year survival rates, and the data on which these are based, for Authority staff after division into those patients diagnosed by Authority medical departments, and those diagnosed externally. No patients were lost to follow-up, but many were diagnosed too recently for full 5-year follow-up.

The classification of patients into "symptom-free" or "with symptoms" at the time of recall after $x$ ray was somewhat arbitrary and could well be criticized. Nevertheless, over the two groups as a whole there were striking differences in survival experience (Table III, overleaf) and this classification would appear well justified.

Eleven patients have been excluded from Table III because details were not recorded of their symptomstate.

\section{Fatal Cases}

Only one case in the present series was picked up by mass miniature radiography outside the Authority. In those who died, survival was longest in those free of symptoms, regardless of the method of discovery (Table IV, overleaf). Authority-discovered patients had better survival times in all categories. The average survival time for all fatal cases was 12.4 months.

\section{OTHER CONDITIONS Noted}

One patient had had both a primary malignant epithelioma of the hand, and a benign lipoma of the arm, 3 years earlier. Another patient survived more than 7 years, dying of a primary colonic cancer. A

TABLE II

U.K.A.E.A. OBSERVED SURVIVAL RATES-1965 FOLLOW-UP

\begin{tabular}{|c|c|c|c|c|c|c|c|c|}
\hline Diagnosis & $\begin{array}{l}\text { Follow-up } \\
\text { Year }\end{array}$ & $\begin{array}{l}\text { No. Died in } \\
\text { Year }\end{array}$ & $\begin{array}{l}\text { Too Recent } \\
\text { for Further } \\
\text { Follow-up }\end{array}$ & $\begin{array}{l}\text { Patients Alive } \\
\text { at Start of } \\
\text { Year }\end{array}$ & $\begin{array}{c}\text { Effective } \\
\text { Number ex- } \\
\text { posed to Risk }\end{array}$ & $\begin{array}{l}\text { Annual } \\
\text { Death } \\
\text { Rate }\end{array}$ & $\underset{\substack{\text { Annual } \\
\text { Rate }}}{\text { Ravival }}$ & $\begin{array}{c}\text { 5-year } \\
\text { Survival } \\
\text { (per cent.) }\end{array}$ \\
\hline Externally & $\begin{array}{l}\text { 1st } \\
\text { 2nd } \\
\text { 3rd } \\
4 \text { th } \\
\text { 5th }\end{array}$ & $\begin{array}{r}60 \\
6 \\
1 \\
0 \\
0\end{array}$ & $\begin{array}{l}\mathbf{0} \\
\mathbf{1} \\
\mathbf{0} \\
\mathbf{0} \\
\mathbf{0}\end{array}$ & $\begin{array}{r}69 \\
9 \\
2 \\
1 \\
1\end{array}$ & $\begin{array}{l}69 \\
8 \cdot 5 \\
2 \\
1 \\
1\end{array}$ & $\begin{array}{l}.870 \\
.706 \\
.500\end{array}$ & $\begin{array}{l}.130 \\
.294 \\
.500\end{array}$ & 1.9 \\
\hline $\begin{array}{l}\text { By the } \\
\text { Authority }\end{array}$ & $\begin{array}{l}\text { 1st } \\
\text { 2nd } \\
\text { 3rd } \\
\text { 4th } \\
\text { 5th }\end{array}$ & $\begin{array}{r}25 \\
19 \\
5 \\
3 \\
3\end{array}$ & $\begin{array}{l}0 \\
4 \\
2 \\
2 \\
0\end{array}$ & $\begin{array}{l}72 \\
47 \\
24 \\
17 \\
12\end{array}$ & $\begin{array}{l}72 \\
45 \\
23 \\
16 \\
12\end{array}$ & $\begin{array}{l}\cdot 347 \\
.422 \\
\cdot 217 \\
\cdot 188 \\
\cdot 250\end{array}$ & $\begin{array}{l}.653 \\
.578 \\
.783 \\
.812 \\
.750\end{array}$ & $18 \cdot 0$ \\
\hline
\end{tabular}


TABLE III

U.K.A.E.A. OBSERVED SURVIVAL RATES IN AUTHORITY-DIAGNOSED PATIENTS-1965 FOLLOW-UP

\begin{tabular}{|c|c|c|c|c|c|c|c|c|}
\hline Symptoms & $\underset{\text { Follow-up }}{\text { Year }}$ & No. Died in & $\begin{array}{l}\text { Too Recent } \\
\text { for Further } \\
\text { Follow-up }\end{array}$ & $\begin{array}{c}\text { Patients Alive } \\
\text { at Start } \\
\text { of Year }\end{array}$ & $\begin{array}{c}\text { Effective } \\
\text { Number ex- } \\
\text { posed to Risk }\end{array}$ & $\begin{array}{l}\text { Annual } \\
\text { Death } \\
\text { Rate }\end{array}$ & $\begin{array}{c}\text { Annual } \\
\text { Survival } \\
\text { Rate }\end{array}$ & $\begin{array}{c}\text { S-year } \\
\text { Survival } \\
\text { (per cent.) }\end{array}$ \\
\hline Absent & $\begin{array}{l}\text { 1st } \\
\text { 2nd } \\
\text { 3rd } \\
4 \text { th } \\
5 \text { th }\end{array}$ & $\begin{array}{r}7 \\
11 \\
3 \\
1 \\
1\end{array}$ & $\begin{array}{l}0 \\
3 \\
2 \\
2 \\
0\end{array}$ & $\begin{array}{r}35 \\
28 \\
14 \\
9 \\
6\end{array}$ & $\begin{array}{l}35 \\
26 \cdot 5 \\
13 \\
8 \\
6\end{array}$ & $\begin{array}{l}\cdot 200 \\
\cdot 415 \\
\cdot 231 \\
\cdot 125 \\
\cdot 167\end{array}$ & $\begin{array}{l}\cdot 800 \\
.585 \\
.769 \\
.875 \\
.833\end{array}$ & $26 \cdot 2$ \\
\hline Present & $\begin{array}{l}\text { 1st } \\
\text { 2nd } \\
\text { 3rd } \\
4 \text { th } \\
5 \text { th }\end{array}$ & $\begin{array}{r}13 \\
5 \\
1 \\
2 \\
2\end{array}$ & $\begin{array}{l}0 \\
1 \\
0 \\
0 \\
0\end{array}$ & $\begin{array}{r}26 \\
13 \\
7 \\
6 \\
4\end{array}$ & $\begin{array}{c}26 \\
12 \cdot 5 \\
7 \\
6 \\
4\end{array}$ & $\begin{array}{l}\cdot 500 \\
\cdot 400 \\
\cdot 143 \\
\cdot 333 \\
\cdot 500\end{array}$ & $\begin{array}{l}.500 \\
.600 \\
.857 \\
.667 \\
.500\end{array}$ & $8 \cdot 6$ \\
\hline
\end{tabular}

TABLE IV

AVERAGE SURVIVAL TIME IN ALL FATAL AUTHORITY CASES

\begin{tabular}{|c|c|c|c|c|c|c|c|c|c|}
\hline \multirow{2}{*}{$\begin{array}{l}\text { Diagnostic } \\
\text { Source }\end{array}$} & \multicolumn{3}{|c|}{ Symptom-Free at Diagnosis } & \multicolumn{3}{|c|}{ With Symptoms at Diagnosis } & \multicolumn{3}{|c|}{ Symptomatology not Recorded } \\
\hline & $\begin{array}{l}\text { No. of } \\
\text { Cases }\end{array}$ & $\begin{array}{c}\text { Average } \\
\text { Survival } \\
\text { (mths) }\end{array}$ & $\begin{array}{c}\text { Survival } \\
\text { Range } \\
\text { (mths) }\end{array}$ & $\begin{array}{l}\text { No.of } \\
\text { Cases }\end{array}$ & $\begin{array}{c}\text { Average } \\
\text { Survival } \\
\text { (mths) }\end{array}$ & $\begin{array}{c}\text { Survival } \\
\text { Range } \\
\text { (mths) }\end{array}$ & $\begin{array}{l}\text { No. of } \\
\text { Cases }\end{array}$ & $\begin{array}{c}\text { Average } \\
\text { Survival } \\
\text { (mths) }\end{array}$ & $\begin{array}{c}\text { Survival } \\
\text { Range } \\
\text { (mths) }\end{array}$ \\
\hline Authority & 25 & 21 & $3-72$ & 24 & 18 & $1-88$ & 8 & 9 & $3-17$ \\
\hline GP and Other & 5 & 11 & $1-34$ & 60 & 7 & $0-87$ & 2 & 7 & $3-10$ \\
\hline External MMR & & & & & & & 1 & 9 & \\
\hline
\end{tabular}

third survived more than 7 years and died of a cerebral haemorrhage at the age of 65 . All other patients died of lung cancer.

Several patients were discovered in the course of an investigation into other diseases. There were two cases in diabetics, one of whom survives 25 months after diagnosis. Not surprisingly, there were 28 cases in which chronic bronchitis was also reported, and, perhaps more unexpectedly, twelve patients with peptic ulcer, most of whom had previously come to surgery for their gastric condition. Three cases of healed tuberculosis were also reported.

\section{Social Class}

With the present age and grade structure of the Authority, for each case of lung cancer arising in a non-manual worker, $2 \frac{1}{2}$ cases could be expected in manual employees. On the other hand, since mortality (and presumably incidence) has been shown to have a rising gradient from Social Class 1 to Class 5 (Registrar-General, England and Wales, 1957) the ratio might well have been about 3.5:1 rather than $2 \cdot 5: 1$. In fact, the ratio in the series was about $5: 1$. This adverse experience does not appear to be occupationally related, and the explanation may well lie in differences of smoking habits; statistics on this point are not available.

BIRTH MONTH AND Mortality

Analysis of the month of birth of the individuals in this series did not confirm the suggestion of
Dijkstra (1963) that an excess of cases arises in those born in February and March.

\section{Discussion}

In the years 1962-5, lung cancer deaths of U.K.A.E.A. male staff and pensioners totalled 82 against the expected 98 . While an occasional "missec case" may occur because of non-pensioned retire ment or departure, it did appear that it might be्] worth investigating what appeared to be a genuinely favourable ratio. One of the possible causes postu lated was the $x$-ray supervision of workers.

It has been suggested (Posner and others, 1963ס Rosenblatt and Lisa, 1956) that routine radiography discovers such a small proportion of the total number of cases that marginal improvements in earlier diag nosis will not perceptibly alter the over-all mortality The present series is not large, but it does suggest that in industry this may not be true.

Galácz (1965) asserts that operation results ares significantly better for cases discovered by mass. miniature radiography cases than for those discovered in other ways, and he quotes a 27 per cent. 5-year survival rate by Berndt and Wolff (1963) in symptomo free patients compared with 4 per cent. for patients

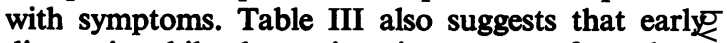
diagnosis while the patient is symptom-free alteres the major impact of mortality from the first to the口 second year, but in spite of this the differences in survival rates in Tables II and III are very realo 
Despite the relatively small numbers, our externallydiagnosed cases provide rates comparable with those of the outside bodies cited.

It is not suggested, at this stage, that the extremely favourable experience of the Authority-diagnosed cases points to more than the need for a wider review in industry generally, and the desirability of a prospective study. But it is not difficult to assume that 6-monthly $x$-ray examinations instead of the present 12-monthly average, would have brought a proportion of those with symptoms into the symptom-free category-the only group, save for rare individual exceptions, in which there was any chance of survival. One could also postulate that a number of those symptom-free, but with readily discernible radiological lesions, might have been caught earlier. Only three patients survived more than 2 years after diagnosis without the aid of surgery. The experience of the South Metropolitan Cancer Registry shows that only one patient in six is judged suitable for surgery (one male in five under the age of 70). Resection was carried out in two out of every three Authority-discovered symptom-free patients.

No obvious complete explanation for this apparent difference is clear. Whilst some of the apparently favourable results from routine radiography in the Authority may be due to the fact that patients in the oldest age groups are virtually excluded and it could be argued that their prognosis is worse, it might also be contended that other interpretations are possible. However, no regular pattern of survival in relation to age has been reported in the literature (Bignall and Moon, 1955; Jones, Robinson, and Meyer, 1955: Gifford and Waddington, 1957). On the other hand, it has been pointed out in the past that the defaulter rate associated with routine $x$-ray examinations, and particularly with repeated routine $x$ rays, may be as high as 27 per cent., even at the first repeat examination (Posner and others, 1963). This is certainly not the case in this industry, and it might well be that Posner's defaulter rate preferentially included those who feared the result of examination. Cuthbert (1959) concluded that, in order to get cases of carcinoma early enough for (effective) treatment, 6-monthly $x$ rays would be necessary. Boucot, Horie, and Sokoloff (1959), who made a plea for semi-annual chest $x$-ray examination of asymptomatic older persons, have now been briefly reported as obtaining disappointing results, but again followup failure is referred to (Journal of the American Medical Association, Medical News Section, 1966).

The value of routine radiography for the diagnosis of cancer of the lung is still controversial; this present series is not large and its contribution must be limited. The original purpose was to examine readily available data to decide whether further research was justified. Tentatively, that question has been answered in the affirmative and the immediate practical effect has been an adjustment of the intervals between $x$-ray examination for different age groups in the Authority. Although the present series is not large, it does suggest that a varying frequency of routine $x$-ray examination may be advisable. Increased frequency of examination over the age of 40 years could be achieved without extra work or cost by decreasing the frequency of examination of those under the age of $\mathbf{4 0}$ years. This adjustment would be consistent with a desire to limit the radiation exposure of younger age groups to the lowest practical level. Until a better screening procedure is devised, the best possible use should be made of radiography. Other perhaps than in immigrants, tuberculosis in males is now more predominant over the age of $\mathbf{4 0}$ than below it.

Perhaps more important is the desire to turn this study into an expanded prospective one. If the experience from a routine industrial health radiology programme is in fact different from that found in other branches of medicine, then a re-orientation of preventive medical plans in some fields might be indicated. The almost negligible defaulter rate is probably the most important factor.

To obtain meaningful results more quickly, it would be valuable if other industries conducting chest radiography would agree to combine in a prospective study.

\section{SUMMARY}

A review of 141 cases of primary lung cancer arising in male employees of the U.K. Atomic Energy Authority showed a 5-year survival rate of 18 per cent. in Authority-diagnosed patients compared with 2 per cent. for those diagnosed externally. A breakdown of cases diagnosed by Authority Medical Departments showed a 5-year survival rate of 26 per cent. for those symptom-free at the time of diagnosis and 9 per cent. for those with symptoms. The effects of routine radiography and its associated defaulter rates are discussed and a larger prospective survey in industry is suggested.

We are grateful to Medical Officers and their staffs at U.K.A.E.A. establishments for obtaining the data studied in this paper, and to Dr J. R. Bignall, Dean of the Institute of Diseases of the Chest, for helpful advice and criticism.

\section{REFERENCES}

Berndt, H., and Wolff, G. (1963). Thoraxchirugie, 10, 556. Bignall, J. R. (1959). Tubercle, 40, 205. and Moon, A. J. (1955). Thorax, 10, 183. 
Boucot, K. R., Cooper, D. A., and Weiss, W. (1961). Ann. intern. Med., 54, 363. , Horie, U., and Sokoloff, M. J. (1959). New Engl. J. Med., 260, 742.

California Tumor Registry (1963). "Cancer Registration and Survival in California". State of California Dept. of Public Health, Berkeley, Calif.

Cuthbert, J. (1959). Brit. J. Dis. Chest, 53, 217.

Dijkstra, B. K. S. (1963). J. nat. Cancer Inst., 31, 511.

Galácz, L. (1965). Radiol. diagn. (Berl.), 6, 335.

Gifford, J. H., and Waddington, J. K. B. (1957). Brit. med. J., 1. 723.

Jones, J. C., Robinson, J. L., and Meyer, B. W. (1955). Arch. Surg., 70, 265.

Journal of the American Medical Association (1966). Medical News Section, p. 46 (vol. 196, No. 3, April 18). Report of speech by K. R. Boucot.

Kutschera, W. (1964). Prax. Pneumol., 18, 379.
Ministry of Health (1960). "Report for the year 19590 Part II: Annual Report of the Chief Medical Officer" H.M.S.O., London.

Posner, E., McDowell, L. A., and Cross; K. W. (1963) Brit. med.J., 2, 1156.

Registrar General (1957). "Decennial Supplement England and Wales, 1951. Occupational Mortality? Part II, vol. 2: Tables". H.M.S.O., London. W (1966). "Statistical Review of England and Wales for the year 1964. Part I: Tables, Medical" H.M.S.O., London.

Rosenblatt, M. B., and Lisa, J. R. "Cancer of the Lung"? Oxford University Press, New York.

Shanks, S. C., and Kerley, P. J. (1962). "A Text-book of X-ray Diagnosis", 3rd ed., vol. 2. Lewis, London.

South Metropolitan Cancer Registry (1960). "Report for: 1958". (1961). "Report for 1959". 